Writers of Italy

\title{
Italo Calvino
}




\title{
Writers of Italy \\ edited by \\ Lino Pertile \\ and \\ Peter Brand
}

Other titles in the series:

\author{
Zygmunt G. Barański and Lino Pertile (eds) \\ The New Italian Novel \\ ISBN 0748609180 \\ Joseph Farrell \\ Leonardo Sciascia \\ ISBN 0748606203 \\ Vivienne Hand \\ Zanzotto \\ ISBN 0748604111
}




\section{Italo Calvino}

MARTIN MCLAUGHLIN

E D I N B URGH UN I VERS IT Y PRESS 
(C) Martin McLaughlin, 1998

Edinburgh University Press

22 George Square, Edinburgh

Typeset in Bembo by

Bibliocraft, Dundee,

and printed and bound in Great Britain

by The University Press, Cambridge

A CIP record for this book is available from the British Library

ISBN 0748607358 (hardback)

ISBN 0748609172 (paperback)

The right of Martin McLaughlin to be identified as author of this work has been asserted in accordance with the

Copyright, Designs and Patents Act 1988. 